\title{
Down-regulation of NF-кB signaling by Gordonia bronchialis prevents the activation of gut epithelial cells
}

\author{
Paola L Smaldini', John Stanford ${ }^{2}$, David E Romanin', \\ Carlos A Fossati' and Guillermo H Docena'
}

\begin{abstract}
The immunomodulatory power of heat-killed Gordonia bronchialis was studied on gut epithelial cells activated with pro-inflammatory stimuli (flagellin, TNF- $\alpha$ or IL-I $\beta$ ). Light emission of luciferase-transfected epithelial cells and mRNA expression of IL-I $\beta$, TNF- $\alpha$, IL-6, CCL20, IL- 8 and MCP-I were measured. NF- $\kappa$ B activation was assessed by immunofluorescence and immunoblotting, and induction of reactive oxygen species (ROS) was evaluated. In vivo inhibitory properties of $G$. bronchialis were studied with ligated intestinal loop assay and in a mouse model of food allergy. $G$. bronchialis promoted the down-regulation of the expression of CCL20 and IL-I $\beta$ on activated epithelial cells in a dosedependent manner. A concomitant blocking of nuclear p65 translocation with increased production of ROS was found. In vivo experiments confirmed the inhibition of CCL20 expression and the suppression of IgE sensitization and hypersensitivity symptoms in the food allergy mouse model. In conclusion, heat-killed $G$. bronchialis inhibited the activation of NF- $\kappa$ B pathway in human epithelial cells, and suppressed the expression of CCL20. These results indicate that $G$. bronchialis may be used to modulate the initial steps of innate immune activation, which further suppress the allergic sensitization. This approach may be exploited as a therapy for intestinal inflammation.
\end{abstract}

\author{
Keywords \\ Down-regulation, Gordonia bronchialis, NF- $\mathrm{B}$, epithelial cells, CCL20, inflammation
}

Date received: 8 February 20I3; revised: 14 July 20I3; I August 20I3; accepted: 9 August 2013

\section{Introduction}

The intestinal immune system has to strike a delicate balance between initiating an inflammatory response against invading pathogens and preventing a reaction against the microbiota that colonizes the lumen, including innocuous Ags. Gut homeostasis involves an intricate and not fully understood crosstalk between the microbiota and the immune system. Intestinal epithelial cells (IEC) play a key role in Ag sampling and modulation of both the innate and adaptive immune response to maintain a controlled inflammation. In this scenario, inflammatory responses against bacterial invasion result in the lumenal secretion of antimicrobial peptides and the release of cytokines and chemokines to recruit and activate different cell subsets. However, these mechanisms, which are mediated by the NF- $\kappa$ B pathway, are also induced in the aberrant immune response (acute and chronic inflammation) observed in different intestinal disorders, such as inflammatory bowel diseases (IBD) and food allergy. ${ }^{1}$ In this study we analyzed the role of heat-killed Gordonia bronchialis on the modulation of activated epithelial cells (ECs), through the down-regulation of the NF- $\mathrm{KB}$ signaling pathway.

Among the aerobic Actinomycetales is a number of genera containing species with remarkable immunemodulating capacities. The first of these to be investigated in recent times was Mycobacterium vaccae.

\footnotetext{
'Laboratorio de Investigaciones del Sistema Inmune, Departamento de Ciencias Biológicas, Universidad de La Plata, La Plata, Argentina

${ }^{2}$ Centre for Infectious Diseases and International Medicine, Windeyer Institute of Medical Sciences, University College London UK and BioEos Ltd, London, UK
}

\section{Corresponding author:}

Guillermo Docena, Laboratorio de Investigaciones del Sistema Inmune, Facultad de Ciencias Exactas, Universidad Nacional de La Plata, Calles 47y II5, C 19002 La Plata, Argentina.

Email: guidoc@biol.unlp.edu.ar 
This species and the closely related Mycobacterium obuense are mycobacteria with immunoregulatory properties, including the down-regulation of Th2 mechanisms and the enhancing of Th1 response, thus providing effective immunotherapeutic reagents. Numerous studies with $M$. vaccae in humans have shown beneficial effects in tuberculosis ${ }^{2}$ and leprosy; ${ }^{3}$ in allergies, such as asthma; $;^{4}$ autoimmune diseases, such as psoriasis; ${ }^{5}$ and cancer. ${ }^{6}$ Over the last few years, species from other genera have been recognized as having similar immunomodulating properties. Several of these non-mycobacterial species, notably G. bronchialis, Rhodococcus coprophilus and Tsukamurella inchonensis have been investigated in a number of experimental and naturally-occurring conditions in animals. In common with all the Actinomycetales, Gordonia species possess powerful cell wall-associated adjuvants and like those of $M$. vaccae, adjuvants of $G$. bronchialis are immunomodulatory. At least two activities on the immune response have been described: immune modulation and suppression of inflammation. ${ }^{7}$

G. bronchialis is a Gram-positive, weakly acid-fast, type species of the genus Gordonia within the sub-order Corynebacteriaceae of the aerobic Actinomycetales. A complete genome sequence of $G$. bronchialis is avail$a_{b l e}^{8}$. It is an environmental organism that rarely gives rise to human infections as a secondary pathogen superimposed on preceding disease of various causes. ${ }^{9}$

Published studies with injected heat-killed $G$. bronchialis and $R$. coprophilus show that they can limit parasitaemia, and the development of chronic focal myocarditis in an experimental rat model of Trypanosoma cruzi infection, ${ }^{10}$ and they can limit the development of myointimal hyperplasia following balloon injury to the common carotid artery in another rat model. ${ }^{11}$ These findings can be attributed to immune modulation resulting from the effect of bacterial adjuvants, combined with bacterial heat-shock proteins that cross-react with mammalian proteins expressed on stressed tissue. In spontaneously-occurring diseases the beneficial effect of treatment with Actinomycetales is seen in dogs with flea-bite allergy and in horses with allergy to midge bites (sweetitch). ${ }^{12}$ In aquacultural medicine, oral administration of $G$. bronchialis and T. inchonensis have shown major benefits in larval survival, control of stress, and growth rates in fishes and shrimps. Oral administration in mammals has also proved successful, with good results in the treatment of tuberculosis in humans with capsules containing $M$. vaccae, ${ }^{13}$ and in horses with sweetitch using capsules containing $T$. inchonensis ( $\mathbf{J}$ Stanford, personal communication).

In this study we investigated whether anti-inflammatory properties could be demonstrated in human and mouse enterocytes exposed to heat-killed G. bronchialis. Dead bacteria were used in vitro and in vivo to suppress the early steps of inflammation through the modulation of IEC, which are heavily involved in the recruitment of immune cells and the induction of the immune response. A question that still awaits answer is whether the effect applies only to acute inflammation in the described models or whether it also applies to true chronic inflammation.

\section{Materials and methods}

\section{Actinomycetales bacteria}

Heat-killed, borate-buffered, aerobic G. bronchialis were provided by BioEos (Marden, UK) as BE-G101. The samples, generated from Ag-free Sauton's medium and prepared as described previously, ${ }^{8}$ were provided as autoclaved suspensions in borate-buffered saline $\mathrm{pH}$ 8 at a concentration of $10 \mathrm{mg}$ wet mass (equivalent to $10^{10}$ ) of organisms per ml. All G. bronchialis treatments in the study were with the homogenized sample, and the numbers refer to the original bacterial numbers estimated for that sample.

\section{Cell culture}

Human colon carcinoma cell lines Caco-2 and Caco-2luciferase (Caco-luc) (Caco-2 cell line transfected with pcc120 Luc plasmid) $)^{14}$ were employed. In Caco-luc cells the luciferase expression is under the control of the CCL20 promoter, which, in turn, is controlled through different NF- $\mathrm{KB}$ binding sites. All cells were grown in DMEM supplemented with $10 \%$ FBS, $100 \mathrm{U} / \mathrm{ml}$ penicillin and $100 \mathrm{mg} / \mathrm{ml}$ streptomycin. Incubations were carried out at $37^{\circ} \mathrm{C}$ in a humidified atmosphere containing $5 \% \mathrm{CO}_{2}$. ECs were cultured with flagellin (FliC) from Salmonella Typhimurium $(1 \mu \mathrm{g} / \mathrm{ml})$, recombinant human TNF- $\alpha$ (rhTNF- $\alpha \quad 10 \mathrm{ng} / \mathrm{ml} ; \quad \mathrm{R} \& \mathrm{D}$, Minneapolis, USA) or IL-1 $\beta$ (10 ng/ml; R\&D).

\section{Reporter gene expression assays}

Caco-luc cells were pre-incubated with $G$. bronchialis $\left(1 \times 10^{9}\right.$ bacteria/well $)$ or with sulfasalazine [1 and $10 \mu \mathrm{M}$ sulfasalazine (SSZ)] (Sigma-Aldrich, St. Louis, MO, USA) for $30 \mathrm{~min}$ and then stimulated with FliC, TNF- $\alpha$ or IL- $1 \beta$ for $6 \mathrm{~h}$ at $37^{\circ} \mathrm{C}$ in complete DMEM medium. Cells were treated with lysis buffer (25 mM Tris-phosphate, $2 \mathrm{mM}$ DTT, $2 \mathrm{mM}$ 1,2-diaminocyclohexane- $N, N, N^{\prime}, N^{\prime}$-tetraacetic acid, $10 \%$ glycerol and 1\% Triton X-100) and luciferase activity was measured using the luciferase substrate (luciferase assay kit; Promega, Madison, WI, USA) following the manufacturer's instructions. Light emission was measured with a luminometer (Luminoscan TL Plus; Labsystem, Jerusalem, Israel). The relative luciferase activity was determined as the ratio of treated/ untreated cell activities. 
Caco-luc cells were pre-incubated with Man (mannose) $(0.1-500 \mathrm{mM})$, or a Man receptor-specific $\mathrm{Ab}$ (BioLegend, San Diego, CA, USA), and G. bronchialis $\left(1 \times 10^{9}\right.$ bacteria) for $30 \mathrm{~min}$. Then cells were activated with FliC for $6 \mathrm{~h}$ and light emission was evaluated.

\section{Western blotting}

Cytoplasmatic and nuclear extracts were obtained from Caco-2 cells that were pre-incubated with $G$. bronchialis for $30 \mathrm{~min}$ and then stimulated with FliC or medium as control for $90 \mathrm{~min}$. Cells were harvested and lysed with $10 \mathrm{mM}$ HEPES, $1.5 \mathrm{mM} \mathrm{MgCl}_{2}, 10 \mathrm{mM} \mathrm{KCl}$ and $0.1 \%$ Nonidet P-40 in the presence of a protease inhibitor mixture (Sigma-Aldrich). After spinning, the cytoplasmic extract was stored at $-80^{\circ} \mathrm{C}$ until used and nuclear pellets were treated with $10 \mathrm{mM}$ HEPES, $1.5 \mathrm{mM}$ $\mathrm{MgCl}_{2}, 0.2 \mathrm{mM}$, EDTA and $20 \%$ glycerol. The soluble fraction was mixed with $10 \mathrm{mM}$ Tris- $\mathrm{HCl}, 60 \mathrm{mM} \mathrm{KCl}$, $10 \%$ glycerol, $0.25 \mathrm{mM}$ EDTA and $0.125 \mathrm{mM}$ EGTA. The amount of protein was determined by bicinchoninic acid assay (Pierce, Rockford, IL, USA). Protein samples were resolved on 10\% SDS-PAGE under reducing conditions (BioRad Mini-Protean III; BioRad, Richmond, CA, USA), and transferred onto a nitrocellulose membrane for $1 \mathrm{~h}$ at $300 \mathrm{~mA}$. Blots were blocked and probed with a rabbit anti-p65 or a mouse anti-pIkB Ab (Santa Cruz, Santa Cruz, CA, USA), followed by the appropriate HRP-conjugated secondary Ab (BioRad). Protein bands were visualized by enhanced chemiluminescence (ECL Plus; GE Healthcare, Bucks, UK) according to the manufacturer's instructions. Blots were stripped and incubated with a rabbit antihuman histone $\mathrm{H} 3$ or $\beta$-actin $\mathrm{Ab}$ (AbCam, Cambridge, UK) diluted 1:1000 and 1:3000, respectively, as an internal loading control. The bands were scanned and quantified using Adobe Photoshop CS software.

\section{Quantitative real time RT-PCR}

Caco-2 cells were incubated for $2 \mathrm{~h}$ with FliC $(1 \mu \mathrm{g} / \mathrm{ml})$, rhTNF- $\alpha(10 \mathrm{ng} / \mathrm{ml})$ or IL- $1 \beta(10 \mathrm{ng} / \mathrm{ml})$ alone or pretreated with $G$. bronchialis $\left(1 \times 10^{9}\right.$ bacteria/well $)$ for $30 \mathrm{~min}$ and then stimulated. Cells were collected and total RNA was isolated using the illustra RNAspin mini isolation kit according the manufacture's specifications (GE Healthcare, Freiburg, Germany). The quality of the extracted RNA was determined by UV absorption and the $\mathrm{OD}$ ratio of $\mathrm{OD}_{280 \mathrm{~nm}} / \mathrm{OD}_{260 \mathrm{~nm}}$ was used as a purity marker. A cDNA preparation was obtained from $1 \mu \mathrm{g}$ of RNA using Moloney Murine Leukemia Virus (M-MLV) reverse transcriptase and random primers (Invitrogen, Life Technologies, Carlsbad, CA, USA). Cytokine and chemokine mRNA expression was determined by real-time quantitative PCR. The experimental procedure was performed with the ABI PRISM sequence detection system using SYBRGreen fluorescence (BioRad). The sequences of the primers were designed with the Perlprimer software using nucleotide sequences present in a GeneBank database. $\beta$-Actin was used as a housekeeping gene to standardize the total amount of cDNA; the genes of interest were chemokine ligand-20 (CCL20), $I L-8$, monocyte chemotactic protein-1 (MCP-1), IL-6, $T N F-\alpha$ and $I L-1 \beta$. Relative mRNA levels $\left(2^{\Delta \mathrm{Cts}}\right)$ were determined by comparing the PCR cycle threshold between cDNA of the gene of interest and that of $\beta$ actin (Cts), and comparing $\mathrm{Cts}$ values between the treated and untreated condition ( $\Delta \mathrm{Cts})$.

\section{ELISA assay for CCL20 quantification}

Confluent Caco-2 cells grown on 48-well plates were incubated with $G$. bronchialis for $30 \mathrm{~min}$ and then stimulated with FliC $(1 \mu \mathrm{g} / \mathrm{ml})$ for $24 \mathrm{~h}$. Supernatant was collected and processed for CCL20 quantification by ELISA, according to the manufacturer's instructions (Human CCL20 ELISA kit; R\&D).

\section{Microscopy techniques}

Caco- 2 cells $\left(1 \times 10^{6}\right.$ cells/well $)$ were grown in a monolayer and then incubated with $G$. bronchialis $\left(1 \times 10^{9}\right.$ bacteria/well) for $30 \mathrm{~min}$, followed by exposure to FliC $(1 \mu \mathrm{g} / \mathrm{ml})$ for $2 \mathrm{~h}$. Washed Caco- 2 cells were fixed in $2 \%$ glutaraldehyde in PBS (pH 7.4) and dehydrated in an ethanol series. For scanning electron microscopy (SEM) cells were coated with gold (15-20 nm) and samples were analyzed with a Philips SEM 505 microscope. Transmission electronic microscopy (TEM) was carried out according to the method described by Hayat. ${ }^{15}$ Cells were treated with $1 \%$ osmium tetroxide to provide contrast to the image, embedded in epoxy resin and cut into thin sections $(90 \mathrm{~nm})$. Finally, samples were treated with uranyl acetate and lead acetate, and then examined in a JEM-1200EX Mark II (JEOL Ltd, Tokyo, Japan) transmission electron microscope.

For fluorescence microscopy cells grown on glass slides were fixed with $4 \%$ paraformaldehyde in PBS ( $\mathrm{pH}$ 7.4), and permeabilized with $0.1 \%$ Triton in PBS. Non-specific binding sites were blocked with $2 \%$ BSA for $30 \mathrm{~min}$, and then cells were incubated with rabbit anti-p65 (Santa Cruz) diluted 1:25 for $60 \mathrm{~min}$ at room temperature, followed by an anti-rabbit Alexa488 conjugated secondary $\mathrm{Ab}$ (Invitrogen, Carlsbad, CA, USA). Propidium iodide $(1 \mu \mathrm{g} / \mathrm{ml})$ was used as a counterstain. An SP5 Leica confocal microscope was used and images were analyzed with LAS AF Lite software (Leica, Wetzlar, Germany). Immunofluorescense microscopy for reactive oxygen species (ROS) assay was done with ECs incubated with G. bronchialis $\left(1 \times 10^{9}\right.$ bacteria/well $), \mathrm{H}_{2} \mathrm{O}_{2}(1 \mathrm{mM})$, butyrate $(5 \mathrm{mM})$ or Hanks buffered saline solution (HBSS) for $30 \mathrm{~min}$. Then, cells were washed 
and incubated in the dark with $3.5 \mu \mathrm{M}$ of 5-(and 6-) chloromethyl-2',7'-dichlorodihydro-fluorescein diacetate, acetyl ester (CM- $\mathrm{H}_{2}$ DCFDA) (Invitrogen) for $15 \mathrm{~min}$. To evaluate if antioxidants could block ROS generation, cells were pretreated with $20 \mathrm{mM} \mathrm{N}$ acetylcysteine (NAC) (Sigma-Aldrich) or the NADPH oxidase inhibitor $10 \mu \mathrm{M}$ diphenyleneiodonium (DPI) (Sigma-Aldrich) for $30 \mathrm{~min}$ before incubation with $G$. bronchialis. Images were acquire using Nikon Eclipse Ti-U microscope (Nikon, Tokyo, Japan).

\section{Image acquisition and processing}

Fluorescence images were acquired using the NISElements F (Nikon), and Image J software was used to merge the different pictures. Confocal images were acquired using the LAS AF Lite software (Leica). The SEM images were automatically transferred during examination using the Scandium SEM Imaging Platform (Olympus, Münster, Germany). TEM images were acquired and processed using the Gatan Digital Micrograph software with an ES1000W Erlanghshen CCM Camera (Model 785). Finally, TIFF images were obtained using Adobe Photoshop CS3 software.

\section{In vivo inhibitory effect of $\mathrm{G}$. bronchialis in the gut}

Male Balb/c mice, 6-8-wks old, 25-30 g of mass (purchased from the School of Animal Science, University of La Plata, La Plata, Argentina), were fasted for $2 \mathrm{~h}$ and anaesthetized by i.p. injection of ketamine $(100 \mathrm{mg} / \mathrm{kg})$ and xylacine $(5 \mathrm{mg} / \mathrm{kg})$. Two ligated loops of the small intestine were made per mouse, as described elsewhere, ${ }^{16}$ and mice were kept anesthetized during the experiment. A suspension of $G$. bronchialis $\left(10^{9}\right.$ bacteria $/ 150 \mu \mathrm{l})$ in saline solution was injected into the lumen alone or with FliC $(250 \mu \mathrm{g})$. Saline solution or FliC was also injected in individual loops, as negative and positive controls, respectively. Two $h$ later mice were killed by cervical dislocation. Loops were collected and washed with saline buffer, Peyer's patches were dissected off and the tissue was homogenized in lysis buffer. Total RNA was isolated and CCL20 gene expression was assessed as previously described. The fold change was defined as the ratio of the normalized values corresponding to loops filled with G. bronchialis, FliC, or $G$. bronchialis and FliC to that filled with saline.

\section{Inhibition of gut inflammation induced by gavage with cholera toxin in mice}

Male 6-8-wk-old Balb/c mice were maintained with water and a commercial diet provided ad libitum. Animals received on consecutive days five intragastric doses of a suspension of $G$. bronchialis $\left(1 \times 10^{9}\right.$ bacteria/ $200 \mu \mathrm{l})$ and then were sensitized by gavage with $10 \mu \mathrm{g}$ of cholera toxin (CT; Sigma-Aldrich) on three consecutive days. Mice were fasted for $2 \mathrm{~h}$, and received 3\% sodium bicarbonate solution to reduce stomach acidity $30 \mathrm{~min}$ before the administration. Two $\mathrm{h}$ after the last administration, animals were killed by cervical dislocation and the gut was excised.

A piece of jejunum was collected, Peyer's patches were dissected off, and the tissue was washed with PBS and then homogenized in lysis buffer. To isolate IEC the jejunum was washed, opened longitudinally and incubated for $10 \mathrm{~min}$ at $4^{\circ} \mathrm{C}$ in buffer A (HBSS supplemented with $100 \mathrm{IU} / \mathrm{ml}$ penicillin, $100 \mathrm{mg} / \mathrm{ml}$ streptomycin and $2 \%$ equine serum) with $1 \mathrm{mM}$ DTT. Then, the tissue was incubated with fresh buffer A plus $0.5 \mathrm{mM}$ EDTA for $20 \mathrm{~min}$ at $37^{\circ} \mathrm{C}$ with vigorous shaking. Supernatant containing ECs was collected, centrifuged and immediately re-suspended in RPMI supplemented with 5\% FBS, penicillin/streptomycin and gentamicin. Total RNA was isolated from the entire tissue, or IEC using the RNA extraction kit, and the gene expression was assessed as previously described.

\section{Intragastric immunomodulation with G. bronchialis in a cow's milk protein food allergy mouse model}

Six 8-wk-old mice were sensitized with six weekly intragastric doses of $20 \mathrm{mg}$ of cow's milk protein (CMP) plus $10 \mu \mathrm{g}$ of CT in a final volume of $200 \mu \mathrm{l}$ of bicarbonate buffer (sensitized mice), as described previously. ${ }^{17}$ To modulate the allergic sensitization, mice received $1 \times 10^{9}$ bacteria of G. bronchialis in $200 \mu \mathrm{l}$ by the oral route twice a week, for $5 \mathrm{wk}$. As controls, naïve mice received six weekly intragastric doses of $20 \mathrm{mg}$ CMP without CT (sham control). Ten d after the last boost mice were challenged by gavage with $20 \mathrm{mg}$ CMP. Blood samples were collected during the sensitization phase and sera were stored at $-20^{\circ} \mathrm{C}$ until used. Twenty-four $h$ after the oral challenge animals were sacrificed by cervical dislocation, and spleens and jejunum were collected.

Levels of serum specific IgE Abs were measured by EAST using cyanogen bromide-activated cellulose paper disks coupled with CMP $(1.75 \mathrm{mg} / \mathrm{ml})$ and developed essentially as described previously ${ }^{17}$. To study $\mathrm{T}$ cell activation, cytokines were measured in supernatants of Ag-stimulated splenocytes. Briefly, $24 \mathrm{~h}$ after the oral challenge mice were killed, spleens were resected and spleen cells were stimulated for $72 \mathrm{~h}$ with CMP $(350 \mu \mathrm{g} / \mathrm{ml})$. Production of IL-5 and IFN- $\gamma$ (Invitrogen) was assayed by ELISA following manufacturer's instructions.

The allergic status of animals was evaluated in vivo by scoring symptoms following the oral challenge (30-60 min), according to Table 1 , in a blinded fashion by two independent investigators. 
Table I. Clinical scores assigned to symptoms triggered following the oral challenge.

\begin{tabular}{ll}
\hline Score & Symptoms \\
\hline 0 & No symptoms \\
I & Scratching and rubbing around the snout and head \\
2 & Puffiness around the eyes and mouth, pilo-erection, reduced activity and/or decreased activity with increased respiratory \\
& rate \\
4 & Respiratory distress, cyanosis around snout and tail \\
5 & No activity upon stimuli, convulsion \\
\hline
\end{tabular}

\section{Statistical analysis}

All statistical analyses were carried out using GraphPad Prism 5 software. The significance of the difference was determined using an independent-sample $t$-test or ANOVA. A $P$-value $<0.05$ was regarded as statistically significant.

\section{Results}

\section{G. bronchialis inhibits the flagellin-induced luciferase activity and NF- $\kappa$ B-dependent CCL20 production}

Initially, we investigated whether $G$. bronchialis exerts biological effects on human ECs. Colonic Caco- 2 cells transfected with $\mathrm{pNF}-\kappa \mathrm{B}$ Luc plasmid on a CCL20 promoter (Caco-luc) were activated for $6 \mathrm{~h}$ with flagellin (FliC), live or dead Salmonella Typhimurium and dead G. bronchialis. Only FliC and Salmonella-induced cell activation (Figure 1a). In order to determine if $\mathrm{Gb}$ exerted any inhibitory effect on activated cells, endothelial cells (EC) were pre-incubated with heat-killed $G$. bronchialis and then exposed to different pro-inflammatory stimuli (FliC, IL1- $\beta$ or TNF- $\alpha$ ). We observed a statistically significant inhibition of cell activation and secretion of CCL20 in pre-treated cells in a doseresponse manner (Figure 1b-d). A significant inhibition of activated cells $(P<0.01)$ was observed with $1000: 1$ and 10:1 bacteria:cell ratios.

The involvement of NF- $\mathrm{BB}$ on cell activation was assessed using SSZ, and we found a complete abrogation of Caco-luc activation when cells were pre-treated with $10 \mu \mathrm{M} \mathrm{SSZ}$ and then stimulated (Figure 2a). To further investigate if $G$. bronchialis exerts an inhibitory effect on EC activation through blocking the NF- $\kappa \mathrm{B}$ pathway, the translocation of p65 into the nucleus was analyzed by immunoblotting (Figure $2 b$ ) and confocal microscopy (Figure 2C). The pre-treatment of FliC-activated cells with $G$. bronchialis modulated the translocation of the NF- $\kappa \mathrm{B}$ component. In resting cells, p65 was retained in the cytosol (Figure 2 ci), while the incubation of cells with FliC induced a more pronounced fluorescence within the nucleus (Figure 2cii), thus indicating the nuclear translocation of p65 as a consequence of NF- $\mathrm{BB}$ activation. The low nuclear fluorescence observed in cells pre-treated with G. bronchialis indicated that translocation of p65 was controlled (Figure 2ciii). A similar effect was observed by immunoblotting (Figure $2 \mathrm{~b}$ ) with a fainter band corresponding to p65 in the nuclear extract of treated cells compared with activated cells. The analysis of $\mathrm{p}-\mathrm{I} \kappa \mathrm{B}$ by immunoblotting revealed that $G$. bronchialis blocked the phosphorylation of this inhibitory component of the NF- $\kappa$ B pathway (Figure 2b). These results demonstrate that dead G. bronchialis exerts an inhibitory effect via suppression of phosphorylation of $\mathrm{p}$-I $\mathrm{B} \mathrm{B}$ with the subsequent blocking of p65 translocation onto the nucleus.

\section{G. bronchialis contact generates the production of ROS in Caco-2 cells}

Evidence is accumulating that ROS are produced in response to bacteria to maintain gut epithelial homeostasis. ${ }^{18}$ We investigated if cells respond to contact with $G$. bronchialis by ROS production. Resting Caco-2 cells rapidly produced ROS upon incubation with dead $G$. bronchialis $\left(\mathrm{H}_{2} \mathrm{O}_{2}\right.$ and butyrate were employed as controls for ROS production) (Figure 3a), and we observed that both G. bronchialis and $\mathrm{H}_{2} \mathrm{O}_{2}$ completely abrogated the luciferase activity in FliC-activated Caco-luc cells (Figure 3b). Then, antioxidant drugs were employed to confirm this effect (Figure 3a). Resting EC treated with the NADPH oxidase inhibitorDPI or with the ROS scavenger NAC, and then incubated with G. bronchialis, did not generate ROS and reversed the inhibitory effect that $\mathrm{Gb}$ exerted on activated cells (Figure 3a, b). These results additionally demonstrate that resting EC express surface receptors that interact with dead bacteria to induce the production of ROS responsible for $\mathrm{NF}-\kappa \mathrm{B}$ inhibition.

\section{The inhibitory effect exerted by G. bronchialis is mediated by cell-bacteria contact and is independent of phagocytosis}

We showed by electron microscopy that dead G. bronchialis is not phagocytised by ECs. All forms 


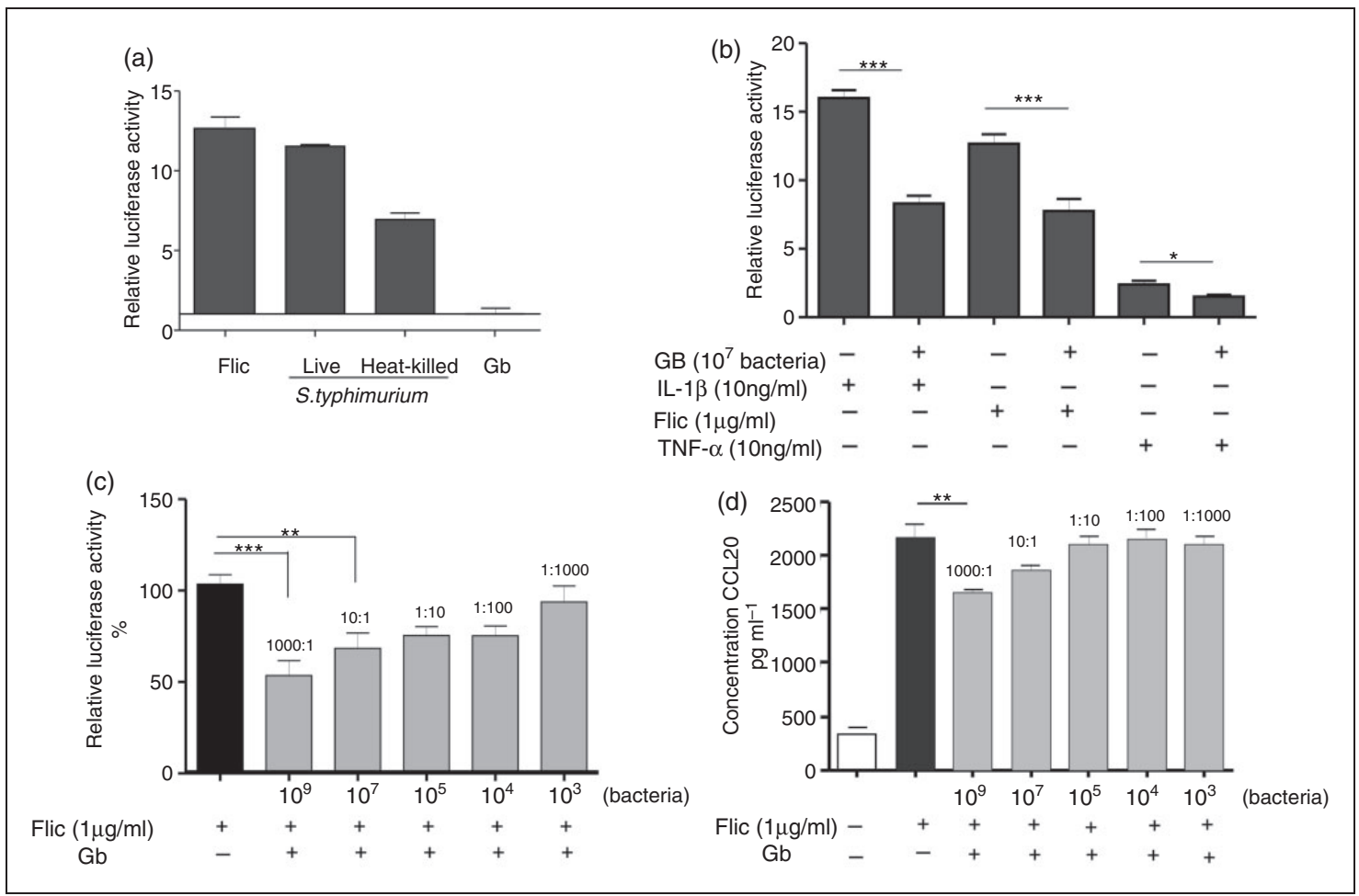

Figure I. Inhibitory effect of Actinomycetales on activated ECs. (a) Caco-luc cells $\left(I \times 10^{6}\right.$ cells/well) were incubated with flagellin (FliC, I $\mu \mathrm{g} / \mathrm{ml})$, heat-killed S. Typhimurium or $\mathrm{G}$. bronchialis $(\mathrm{Gb})$, or live S. Typhimurium $\left(\mathrm{I} \times 10^{7}\right.$ bacteria/well) for $6 \mathrm{~h}$ and light emission was measured. (b) Caco-luc cells were incubated with $\mathrm{G}$. bronchialis $\left(\mathrm{I} \times 10^{7}\right.$ bacteria/well) for 30 min and then exposed to ILI $\beta(10 \mathrm{ng} / \mathrm{ml})$, FliC $(\mathrm{I} \mu \mathrm{g} / \mathrm{ml})$ or TNF- $\alpha(10 \mathrm{ng} / \mathrm{ml})$ for $6 \mathrm{~h}$. Light emission was measured. (c) Caco-luc cells were incubated with different quantities of $G$. bronchialis (bacteria:cell ratio is indicated) and then activated with FliC for $6 \mathrm{~h}$. Light emission was measured. Results are expressed as relative light emission of cells incubated with stimulus versus medium. Data are expressed as mean values of luciferase activity \pm SEM. (d) Cells were incubated with $G$. bronchialis for $30 \mathrm{~min}$ and then activated with FliC for $24 \mathrm{~h}$. Supernatants were evaluated for CCL20 concentration by ELISA. Results are representative of at least three independent experiments. $* P<0.05$, $* * P<0.01, * * * p<0.005$.

of microscopy showed that bacteria are attached to the cell surface and no bacteria could be intracellularly evidenced. Figure 4 (a, b) shows that bacteria can either be found free or in cluster only in activated cells, with a typical bacillus shape of the order Actinomycetales. Attachment of $G$. bronchialis to Caco-2 cells was studied by electron microscopy. Of note, membrane protrusions of ECs trapping bacilli could be seen by SEM (Figure 4b).

Based on the information that the $G$. bronchialis envelope contains lipoarabinomannans, ${ }^{19}$ we studied the involvement of carbohydrates in cell:bacteria interactions. Caco-luc cells were pre-incubated with different concentration of Man, followed by incubation with $G$. bronchialis and FliC. We found a Man dosedependent reversion of the inhibition exerted by $G$. bronchialis (Figure 4c). Besides, blocking the Man receptor with a specific $\mathrm{Ab}$ reverted the inhibition promoted by $G$. bronchialis in activated cells (Figure 4d). Overall, the inhibitory effect of $G$. bronchialis on colonic EC is dependent neither on bacterial viability nor on the presence of released components of the cell wall, and the Man receptor might be implicated in suppression.

\section{G. bronchialis inhibits the induction of cytokine and chemokine mRNA expression}

Different cytokines and chemokines released by intestinal EC are involved in the early activation of innate immunity. To study and quantify the inhibitory effect of G. bronchialis on the gene-transcription of pro-inflammatory mediators, we analyzed the gene expression pattern of Caco- 2 cells. Cells were treated with different stimuli (FliC, IL-1 $\beta$ and TNF- $\alpha$ ) with or without $G$. bronchialis for $2 \mathrm{~h}$. A differential induction of mRNA expression corresponding to $I L-1 \beta$, $I L-6, T N F-\alpha, C C L 20, I L-8$ and $M C P-1$ upon incubation with the different stimuli was observed (Figure 5A, B). Stimulation with FliC and IL-1 $\beta$ caused significant induction of CCL20 (4530-fold and 1940-fold, respectively) and $T N F-\alpha$ (20.2-fold and 5.6-fold, respectively) compared with untreated cells. We also found that TNF$\alpha$ induced a poor cytokine and chemokine response. 


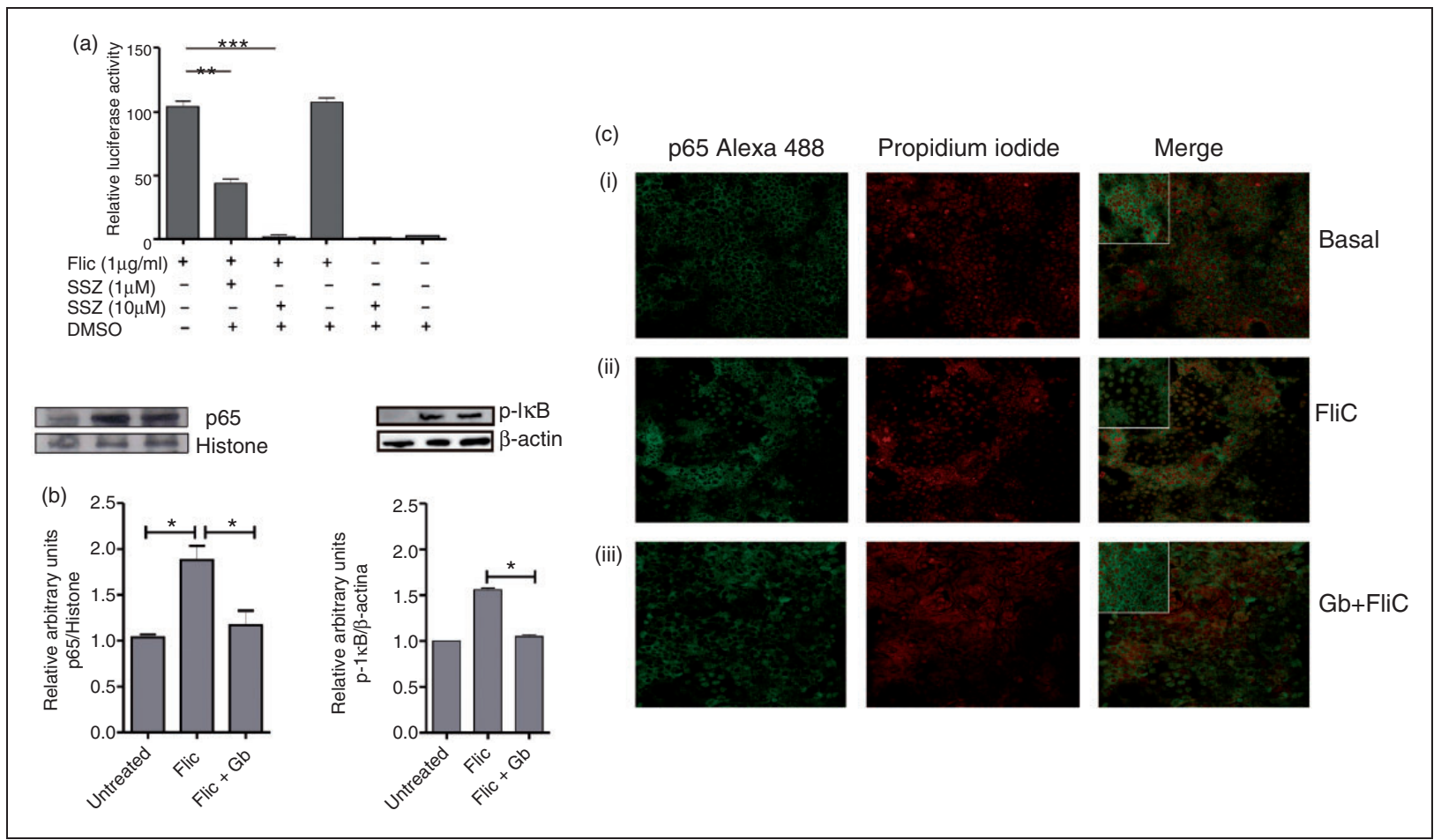

Figure 2. Modulatory effect of Actinomycetales on NF- $\kappa B$ activation. FliC-activated Caco-luc cells $\left(I \times 10^{6}\right.$ cells/well) were pre-treated with I or $10 \mu \mathrm{M}$ of SSZ and light emission was measured. Results are expressed as relative light emission of treated cells versus untreated cells (medium) (b) Caco-2 cells $\left(\mathrm{I} \times 10^{6}\right.$ cells $/$ well) were incubated with FliC $(\mathrm{I} \mu \mathrm{g} / \mathrm{ml}), \mathrm{FliC}(\mathrm{I} \mu \mathrm{g} / \mathrm{ml}) \mathrm{plus}$ G. bronchialis $(\mathrm{Gb})\left(1 \times 10^{9}\right.$ bacteria/well) or medium for $90 \mathrm{~min}$. The nuclear extract was obtained for detection of p65 and histone $\mathrm{H} 3$ as internal control (left panel), and the cytoplasmic extract was used for detection of $\mathrm{p}$-IB and $\beta$-actin as internal control (right panel) by immunoblotting. (c) Caco-2 cells were grown in monolayer on glass slides and the presence of p65 was analyzed by confocal microscopy using a rabbit anti-p65 primary Ab, followed by an anti-rabbit AlexaFluor 488-conjugated as secondary $\mathrm{Ab}$ (green). Propidium iodide was used to stain the nucleus (red); (i) untreated cells $\left(\mathrm{I} \times 10^{6}\right.$ cells/well); (ii) cells ( $\mathrm{I} \times 10^{6} /$ well) activated with Flic $(I \mu \mathrm{g} / \mathrm{ml})$ for $90 \mathrm{~min}$; (iii) Flic-activated cells with $\mathrm{G}$. bronchialis $\left(\mathrm{I} \times 10^{9}\right.$ bacteria/well). Magnification $200 \times$.

Consistent with previous results G. bronchialis did not activate resting ECs. We observed a differential modulation of cytokine and chemokine gene expression depending on the inflammatory stimulus with $1 \times 10^{9}$ bacteria (Figures $5 \mathrm{c}-\mathrm{f}$ ). When EC were pre-treated with G. bronchialis for $30 \mathrm{~min}$ and then stimulated with FliC for $2 \mathrm{~h}$ we found a significant down-modulation of mRNA expression of CCL2O $(P<0.01)$ and $I L-8$ $(P<0.005)$, with a decrease in $I L-1 \beta$ and $I L-6$. Furthermore, when G. bronchialis-pre-treated cells were activated with IL-1 $\beta$, a significant suppression of mRNA expression corresponding to $C C L 20(P<0.05)$ and $T N F-\alpha(P<0.01)$ was observed, with a decrease in $I L-1 \beta$ and $I L-6$. The gene expression of $M C P-1$ was not modified with bacteria incubation.

\section{G. bronchialis promotes in vivo inhibition of CCL20 gene expression in the gut of Balb/c mice}

To study the physiologic relevance of the gene transcription suppression promoted by G. bronchialis, we performed duodenal intralumenal injection of FliC,
G. bronchialis, FliC plus G. bronchialis or saline in different ligated intestinal loops in the small bowel of Balb/c mice. The CCL2O mRNA expression in the whole tissue was quantified and we found a statistically significant inhibition of gene expression with a suspension of $1 \times 10^{9} \mathrm{G}$. bronchialis compared with loops filled with FliC (Figure 6a) $(P<0.01)$. As expected, loops filled with $G$. bronchialis alone showed no induction of CCL2O gene expression. This clearly suggests that G. bronchialis does not activate mucosal cells, whereas FliC-activated cells can be influenced in vivo by the presence of heat-killed G. bronchialis.

Given the selective inhibition of cytokine and chemokine gene expression, we then sought to examine the effect of $G$. bronchialis in a different pro-inflammatory mucosal setting. Balb/c mice received five doses of a suspension of $G$. bronchialis by gavage, followed by three doses of CT intragastrically on separate days. $C C L 20, M C P-1$ and $I L-1 \beta$ mRNA expression was analyzed in the jejunum and in isolated enterocytes. We observed that the CT-driven inflammation of the gut produced a CCL2O mRNA up-regulation in EC and 


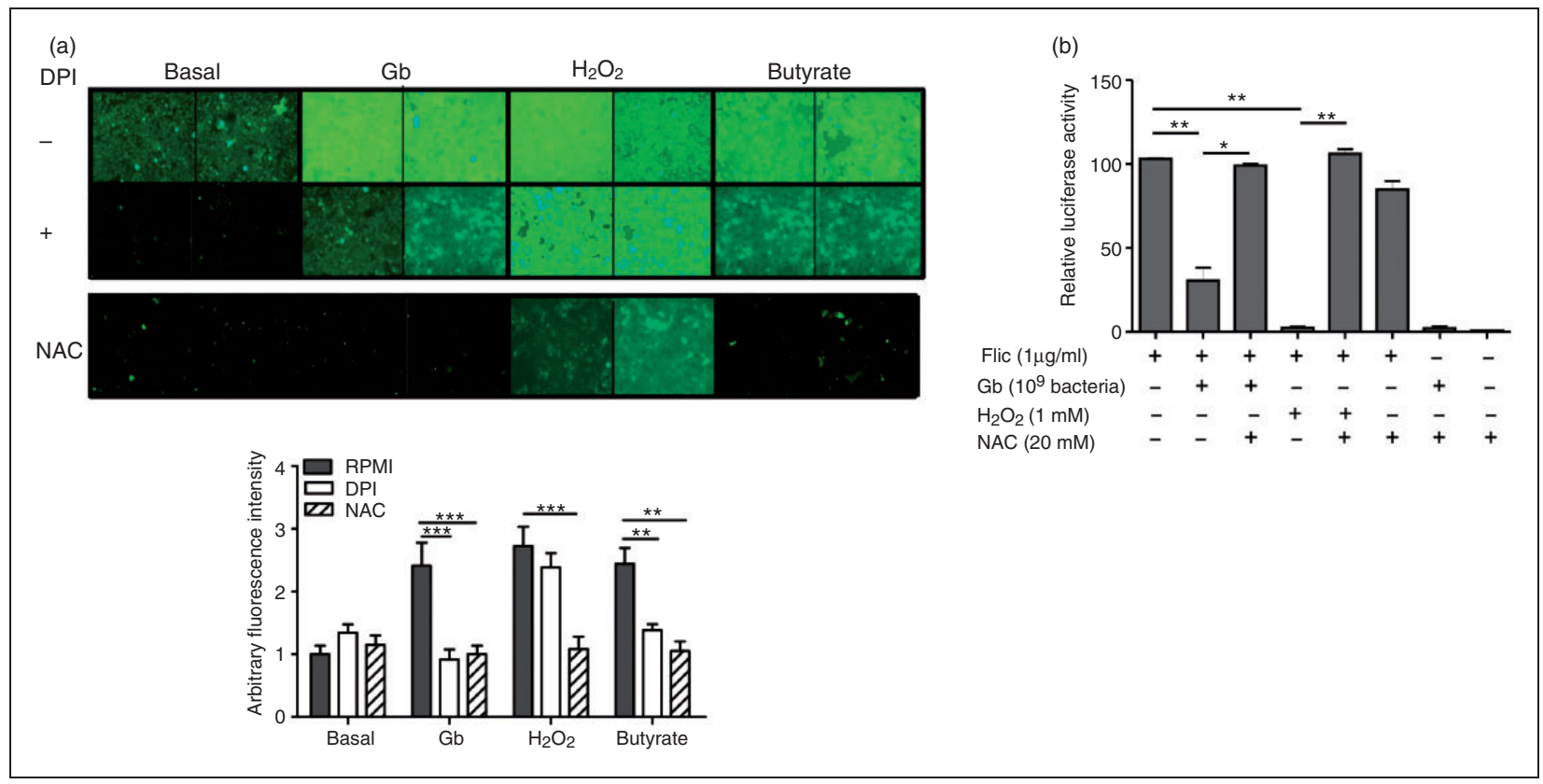

Figure 3. Induction of ROS by $G$. bronchialis $(\mathrm{Gb})$ and inhibition of Caco-luc cells. ROS were revealed by fluorescence microscopy with 5-(and 6)-chloromethyl-2',7'-dichlorodihydro-fluorescein diacetate, acetyl ester $\left(\mathrm{CM}-\mathrm{H}_{2} \mathrm{DCFDA}\right)(3.5 \mu \mathrm{M})$ on Caco-2 cells incubated with PBS, G. bronchialis $\left(\mathrm{I} \times 10^{9}\right.$ bacteria/well), $\mathrm{H}_{2} \mathrm{O}_{2}(\mathrm{I} \mathrm{mM})$ and butyrate $(5 \mathrm{mM})$, with and without the antioxidants DPI $(10 \mu \mathrm{M})$ and NAC $(20 \mathrm{mM})$. Fluorescence images were acquired and processed. (B) Caco-luc cells $\left(1 \times 10^{6}\right.$ cells/well) were incubated with $\mathrm{G}$. bronchialis $\left(\mathrm{I} \times 10^{9}\right.$ bacteria/well) or $\mathrm{H}_{2} \mathrm{O}_{2}(\mathrm{I} \mathrm{mM})$ and the antioxidant $\mathrm{NAC}(20 \mathrm{mM})$ and then exposed to FliC. Light emission was measured. All the results are representative of at least three independent experiments. $* P<0.05$, $* * P<0.01, * * * P<0.005$.

in the jejunum of treated animals, whereas $M C P-1$ was only found increased in the whole tissue (Figure 6b). Mice gavaged with $G$. bronchialis showed a more pronounced inhibition of CCL2O gene expression $(P<0.005)$ in enterocytes than in the jejunum tissue $(P<0.01)$, whereas no modulation of $M C P-1$ gene transcription was observed. CT also did not induce an up-regulation of $I L-1 \beta$ gene expression. In conclusion, CT-driven inflammation was modulated in vivo with G. bronchialis intragastrically and enterocytes are the main target cells for CCL20 modulation.

Finally, we used a food allergy mouse model to evaluate the immunomodulatory capacity of G. bronchialis in an Ag-dependent inflammatory condition. Orally-sensitized mice with CMP as allergen plus CT as mucosal adjuvant, ${ }^{17}$ and simultaneously treated with $G$. bronchialis intragastrically or saline were challenged intragastrically with CMP to see if symptoms were elicited upon exposition to the allergen (Figure $6 \mathrm{c}$ ). We observed that minutes after the oral challenge sensitized animals treated with $G$. bronchialis showed a lower clinical score than saline-treated sensitized mice (Figure 6d). During the sensitization phase CMP-specific IgE and IL-5 were induced in sensitized mice, which reflects a CT-biased Th2-immune response induction that led to allergic sensitization. The administration of $G$. bronchialis suppressed the oral sensitization-promoted CMP-specific IgE by B cells (Figure 6e) and IL- 5 by splenocytes, while IFN- $\gamma$ remained unchanged (Figure 6f). To characterize the mucosal response $I L-5, I F N-\gamma$, Gata-3 and T-bet gene expression was determined in jejunum lamina propria. We found a reduction of $I L-5$ and Gata-3 gene expression in animals that received G. bronchialis orally (Figure $6 \mathrm{~g}$ ). Overall, these results demonstrate that G. bronchialis administration by the oral route modulates the innate and adaptive immune response induced in the gut mucosa, with a clear reduction of hypersensitivity symptoms, serum-specific IgE level, systemic Th2-associated cytokines and mucosal markers.

\section{Discussion}

IECs lining the gut have a critical role in the management of exogenous Ags that contact the apical side and the immune system through the basolateral side. The intracellular signaling that is switched on or off in these cells is intimately involved in the ability to balance tolerance and protective immunity. In the present work we studied the inhibitory effect that G. bronchialis exerts on the human ileocecal epithelial carcinoma cell line Caco-2. Several pro-inflammatory cytokines and chemokines were induced in Caco- 2 cells activated in vitro with FliC, IL-1 $\beta$ or TNF- $\alpha$. We have previously studied the kinetics of cell activation and we found that $2 \mathrm{~h}$ after stimulation the mRNA corresponding to proinflammatory mediators peaked (results not shown). Furthermore, we found that FliC and IL-1 $\beta$ were the 

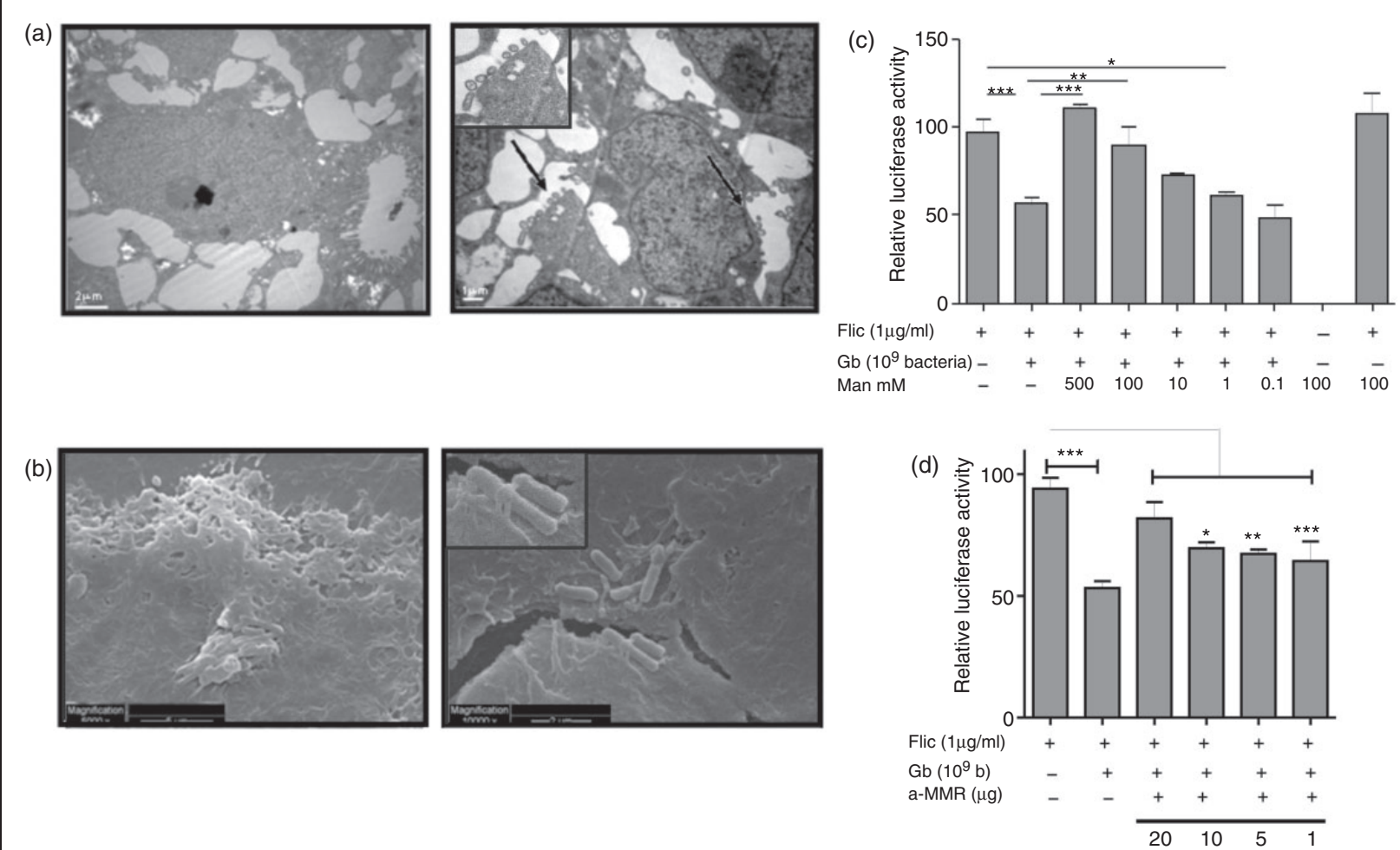

Figure 4. Electron microscopy of Caco-2 cells with $G$. bronchialis $(\mathrm{Gb})$. Resting or FliC-activated Caco- 2 cells $\left(I \times 10^{6}\right)$ were incubated with heat-killed $\mathrm{G}$. bronchialis $\left(1 \times 10^{9}\right.$ bacteria) for $2 \mathrm{~h}$ and analyzed by electron microscopy. (A) TEM of resting (left) and FliCactivated cells (right). Arrows indicate bacteria adhered to membrane cells. Dead bacteria attached to the cell surface is depicted. Original magnification, 12,000×. (B) SEM of FliC-activated cells with bacteria attached. Magnifications of $5000 \times($ left) and $10,000 \times($ right $) .(\mathrm{C})$ Caco-luc cells $\left(I \times 10^{6}\right.$ cells/well) were co-incubated with $\mathrm{G}$. bronchialis $\left(\mathrm{I} \times 10^{9} /\right.$ well $), \mathrm{Man}(0.1-500 \mathrm{mM})$ and $\mathrm{FliC}$ $(\mathrm{l} \mu \mathrm{g} / \mathrm{ml})$ for $6 \mathrm{~h}$. Cells were lysed and light emission was measured. Results are expressed as relative light emission of treated cells to cells incubated with medium. (D) FliC-Caco-luc activated cells were co-incubated with G. bronchialis and different concentrations of the specific $A b$ to the Man receptor (a-MMR). Light emission was measured. Results are representative of at least three independent experiments. $* P<0.05$, $* * P<0.01$, *** $P<0.005$.

most potent activators for IEC, which reflects what is already known about a higher expression of specific receptors. ${ }^{20}$ Although it has been described that the Caco-2 cell line constitutively expresses mRNA of $I L-1 \beta, I L-8$ and $M C P-1,{ }^{21}$ these inflammatory mediators were significantly up-regulated upon activation (more than fourfold). Remarkably, CCL20, which recruits immature dendritic cells and $\mathrm{T}$ lymphocytes to mucosal target sites, ${ }^{22}$ showed the most significant increase in activated cells (increase of more than 1800fold). These results suggest that the Caco- 2 cell line constitutes a useful mucosal EC line to study the effect of different activators and modulators of the immune response. ${ }^{23}$ In this study, we used dead $G$. bronchialis to investigate the modulation of the early steps of IEC activation. A clear in vivo and in vitro inhibition of CCL20 gene expression was found, which indicates that these bacteria may interfere with the cell recruitment that mediates inflammation and induction of innate and adaptive immune responses.

One of the central transcription factors that mediates inflammatory responses is NF-kB. ${ }^{24}$ This family of transcription factors is known to play a key role in promoting the expression of cytokines and chemokines through the interaction with different cofactors in the nuclear gene promoter regions in response to enteric microorganisms. ${ }^{25}$ All of the transcriptional responses induced in Caco- 2 cells with FliC, IL-1 $\beta$ or TNF- $\alpha$ are initiated by $\mathrm{NF}-\kappa \mathrm{B}$ activation, with the phosphorylation of I $\mathrm{K} B$ kinases and the release of $\mathrm{p} 65$. The former is degraded through the proteasome, and the latter is translocated into the nucleus to bind specific DNA sequences resulting in induction of gene expression of pro-inflammatory immune mediators. ${ }^{26}$ Our study showed, for the first time, that the immunomodulatory Actinomycetales have the ability to suppress the pro-inflammatory $\mathrm{NF}-\kappa \mathrm{B}$ signaling activation, which was indirectly evidenced through the modulation of CCL2O gene expression and secretion. We found that dead G. bronchialis induced the production of ROS, which inhibited the phosphorylation of $I \kappa B$, and, hence, the translocation of p65 onto the nucleus. Similar protective effects of ROS have been described for live bacteria and yeast of the microbiota 


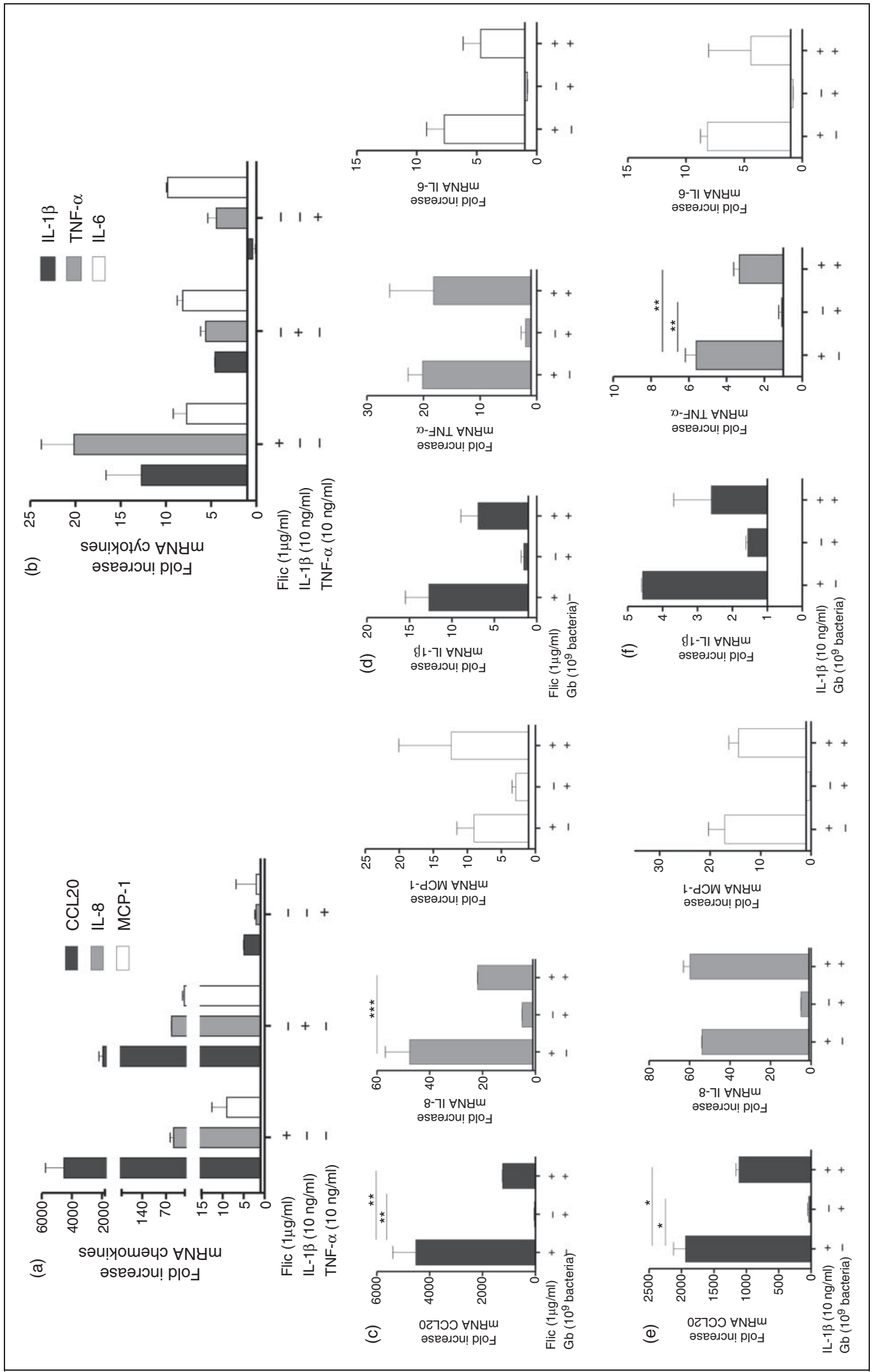

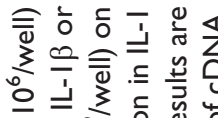

으롤

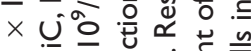

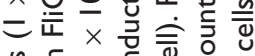

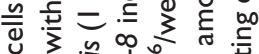

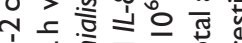

o 건

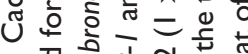

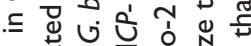

ธ。

ษิ

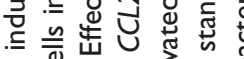

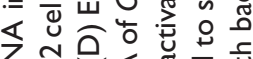

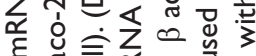

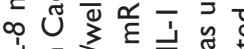

ᄀ. $\cong 0003$

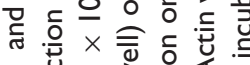

ปิ่

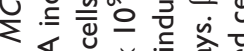

ปิ่

है हु

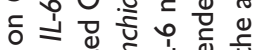

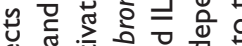

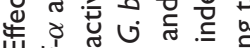

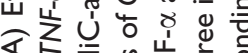

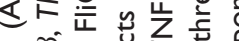

은.

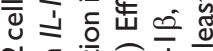

กิ

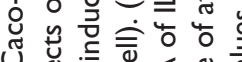

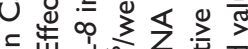

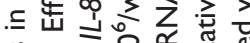

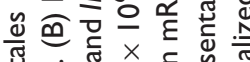

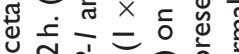

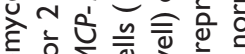

은

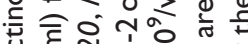

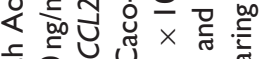

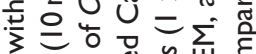

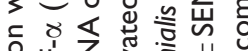

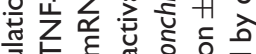

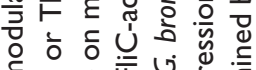

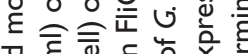

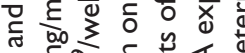

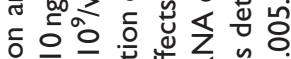
은 은 焉娄

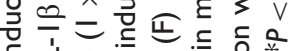

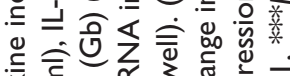

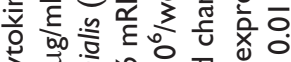
仓ิ는

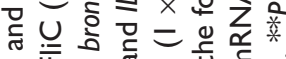
凹 立 乐

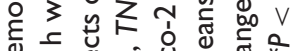

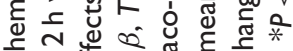

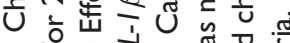

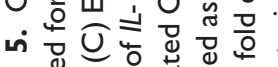

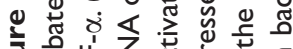

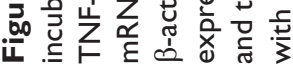




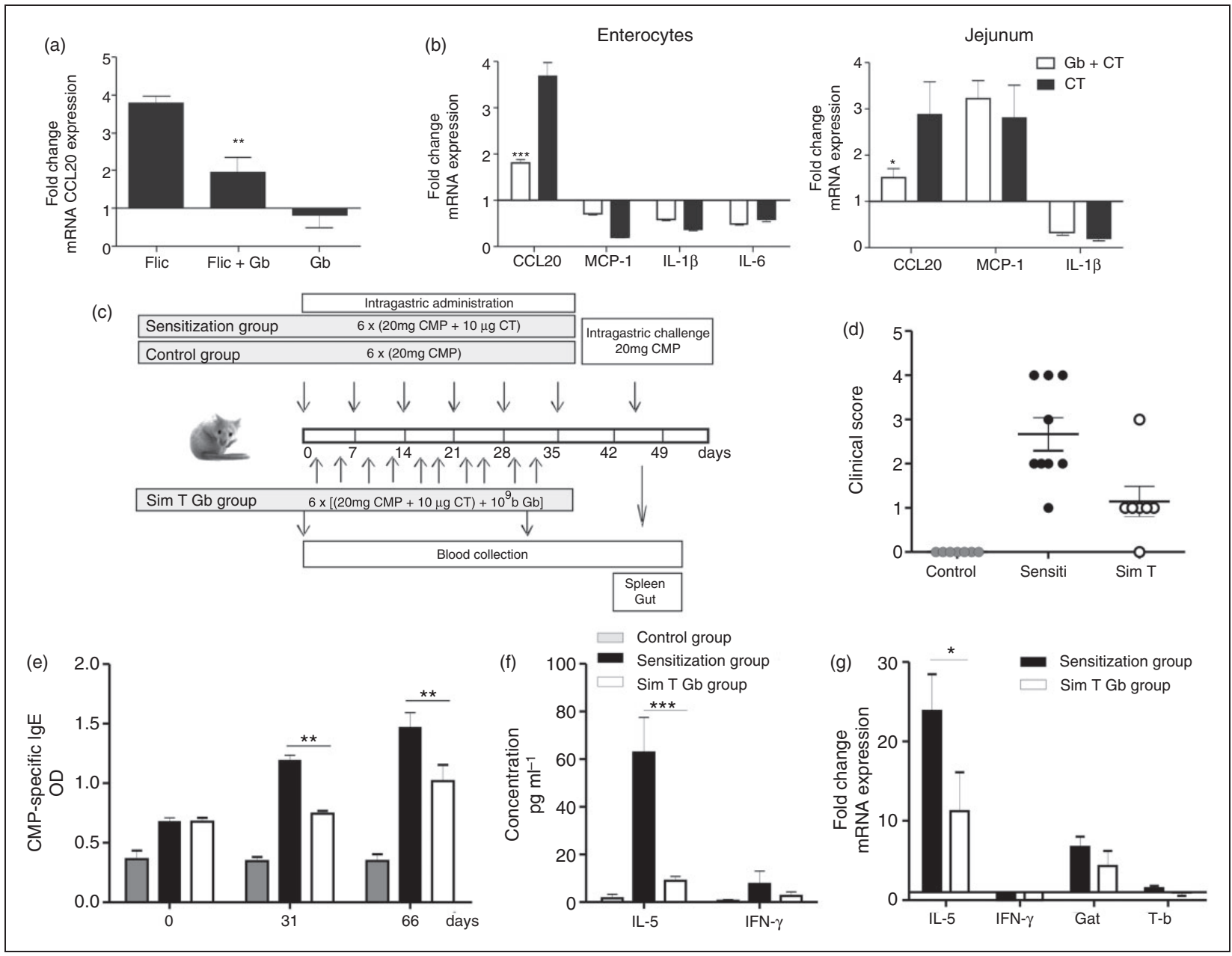

Figure 6. In vivo modulation of CCL20 mRNA expression and treatment of a food allergy mouse model. (a) The lumen of intestinal loops in Balb/c mice were injected with $\mathrm{G}$. bronchialis $\left(\mathrm{I} \times 10^{9}\right.$ bacteria/200 $\left.\mu \mathrm{l}\right)$, FliC $(250 \mu \mathrm{g})$, G. bronchialis $(\mathrm{Gb})$ and $\mathrm{FliC}$, or saline and left for $2 \mathrm{~h}$ in anesthetized animals. Excised jejunum was analyzed for CCL20 mRNA induction. $\beta$-Actin gene expression was used to normalize the amount of cDNA. Results are expressed as fold change in mRNA expression \pm SEM comparing the standardized amount of cDNA corresponding to the loops filled with G. bronchialis, FliC or G. bronchialis and FliC to that of saline. Results are representative of three independent experiments. (b) Balb/c mice were gavaged with CT (IO $\mu \mathrm{g})$ and then with $G$. bronchialis $\left(1 \times 10^{9}\right.$ bacteria/mouse). Cytokine and chemokine mRNA expression was analyzed in both jejunum and enterocytes. $\beta$-Actin gene expression was used to normalize the amount of cDNA and results are expressed as fold change in mRNA expression \pm SEM comparing standardized amounts of cDNA corresponding to sensitized and treated mice with that in sensitized, but untreated, mice. Results are representative of three independent experiments. (c) Balb/c mice were sensitized as shown in the schematic drawing of the experimental protocol (control groups are included). (d) Clinical scores of mice 30-60 min following the oral challenge with CMP; each point represents an individual mouse (see Table I). (e) Serum level of CMP-specific lgE during sensitization and treatment with $G$. bronchialis. (f) IL-5 and IFN- $\gamma$ concentration in supernatants of spleen cells collected $24 \mathrm{~h}$ following the oral challenge and activated in vitro with $350 \mu \mathrm{g} / \mathrm{ml}$ of CMP for $72 \mathrm{~h}$. (g) mRNA expression for cytokines (IL-5 and IFN- $\gamma$ ) and transcription factors (T-bet and GATA-3) was quantified in jejunum $24 \mathrm{~h}$ following the oral challenge. Results correspond to two independent experiments with eight animals per group. $* P<0.05, * * P<0.0$ l, $* * * P<0.005$.

through the production of butyrate. ${ }^{18,23,27}$ We also demonstrated that this inhibitory effect exerted by G. bronchialis is not dependent on phagocytosis, and Man-specific receptors on the membrane of IEC could be implicated.

FliC used as cell stimulator mimics the scenario of IBD, ${ }^{28,29}$ as bacterial flagellin from the microbiota is a dominant $\mathrm{Ag}$ that activates innate immunity ${ }^{28}$ with an aberrant NF-kB activity and CCL20 overexpression $^{30}$. Dendritic cells and $\mathrm{T}$ cells that are continually attracted into the gut wall ${ }^{31}$ sustain the increased levels of IL-1 $\beta$ and TNF- $\alpha$, which mediate the intestinal inflammation. ${ }^{32}$ Therefore, the in vitro conditions here used to activate colonic ECs may represent the mucosal condition of gastrointestinal inflammatory disorders. In this sense dead $G$. bronchialis 
could have a role in controlling inflammation in the colonic mucosa.

We also included in our work $\mathrm{CT}$ as a potent mucosal adjuvant that abrogates oral tolerance. It has been demonstrated in mice that in CT-driven inflammation the innate mediators IL- $1^{33}$ and CCL2 $0^{34}$ are up-regulated, followed by a Th2-biased adaptive immune response that mimics the effector phase of a food allergy. ${ }^{17,35}$ In the IgE-mediated food allergy mouse model we found that the orally administered dead $G$. bronchialis reversed the up-regulated mucosal CCL20 gene transcription in the whole tissue and, particularly, in IEC. Furthermore, the oral administration of dead G. bronchialis down-regulated the production of the Th2-associated IgE Ab isotype, the signature cytokine secretion, the gene expression of CCL20, $I L-5$ and $G A T A-3$ at the mucosal site and, most importantly, the symptoms associated with hypersensitivity reactions in sensitized mice. No evidence of Th1 immune response induction was found. It has been demonstrated in asthma mouse models that other Actinomycetales genera induce Treg, which, in turn, reverts the allergic status of mice. ${ }^{36}$ This mechanism needs to be explored in our food allergy model.

Several studies have focused on the potential use of these Actinomycetales bacteria in anti-inflammatory interventions. However, few data are available on intestinal models and here we provide evidence that dead G. bronchialis exerts a mucosal modulation upon administration of flagellin and CT.

\section{Conclusions}

Our results demonstrate that dead G. bronchialis bacteria inhibit the TNF- $\alpha-$, IL-1 $\beta$ - or flagellin-induced $\mathrm{NF}-\kappa \mathrm{B}$ activation, and $C C L 2 O$ gene transcription in human ECs and in mouse intestine. We demonstrated that bacteria induced the production of ROS, which impairs the translocation of p65 into the nucleus and further gene expression of cytokines and chemokines. We also used this bacterium through the oral route to control the allergic reaction and mucosal inflammation in a food allergy mouse model. The inhibitory effect promoted by $G$. bronchialis might have potential applications in therapeutic strategies attempting to control innate immunity in inflammatory intestinal disorders.

\section{Funding}

This work was supported by the Argentinean Agency for Promotion of Science and Technology (grant numbers PICT 25417, PICT 2202), and the CONICET (grant number PIP 5475).

\section{Conflicts of interest}

The authors do not have any potential conflicts of interest to declare.

\section{Acknowledgements}

GHD and CAF are researchers of the Argentinean National Research Council (CONICET). BioEos Ltd provided the reagents prepared from Gordonia bronchialis (BE-G101). We thank veterinarian Pablo Stringa for technical assistance.

\section{References}

1. Hayden MS, West AP and Ghosh S. NF-kappaB and the immune response. Oncogene 2006; 25: 6758-6780.

2. Dlugovitzky D, Stanford C and Stanford J. Immunological basis for the introduction of immunotherapy with Mycobacterium vaccae into the routine treatment of TB. Immunotherapy 2011; 3: $557-568$.

3. Truoc LV, Ly HM, Thuy NK, Trach DD, Stanford CA and Stanford JL. Vaccination against leprosy at Ben San Leprosy Centre, Ho Chi Minh City, Vietnam. Vaccine 2001; 19: 3451-3458.

4. Camporota L, Corkhill A, Long H, Lordan J, Stanciu L, Tuckwell N, et al. The effects of Mycobacterium vaccae on allergen-induced airway responses in atopic asthma. Eur Respir $J$ 2003; 21: 287-293.

5. Lehrer A, Bressanelli A, Wachsmann V, Bottasso O, Bay ML, Singh M, et al. Immunotherapy with Mycobacterium vaccae in the treatment of psoriasis. FEMS Immunol Med Microbiol 1998; 21: 71-77.

6. Stanford JL, Stanford CA, O'Brien MER and Grange JM. Successful immunotherapy with Mycobacterium vaccae in the treatment of adenocarcinoma of the lung. Eur J Cancer 2008; 44: 224-227.

7. Bottasso O, Docena G, Stanford JL and Grange JM. Chronic inflammation as a manifestation of defects in immunoregulatory networks: implications for novel therapies based on microbial products. Inflammopharmacology 2009; 17: 193-203.

8. Ivanova N, Sikorski J, Jando M, Lapidus A, Nolan M, Lucas S, et al. Complete genome sequence of Gordonia bronchialis type strain (3410). Stand Genomic Sci 2010; 2: 19-28.

9. Arensko M, Bro D and Steinbu A. Biology of the metabolically diverse genus Gordonia. Appl Environ Microbiol 2004; 70: 3195-3204.

10. Fontanella GH, Pascutti MF, Daurelio L, Perez AR, Nocito AL, Wojdyla D, et al. Improved outcome of Trypanosoma cruzi infection in rats following treatment in early life with suspensions of heat-killed environmental Actinomycetales. Vaccine 2007; 25: 3492-3500.

11. Hansrani M, Stanford J, McIntyre G, Bottasso O and Stansby G. Immunotherapy for the prevention of myointimal hyperplasia after experimental balloon injury of the rat carotid artery. Angiology 2010; 61: 437-442.

12. Marro A, Pirles M, Schiaffino L, Bin L, Dávila H, Bottasso OA, et al. Successful immunotherapy of canine flea allergy with injected Actinomycetales preparations. Immunotherapy 2011; 3: 971-978.

13. Dlugovitzky D, Notario R, Martinel-Lamas D, Fiorenza G, Farroni M, Bogue C, et al. Immunotherapy with oral, heatkilled, Mycobacterium vaccae in patients with moderate to advanced pulmonary tuberculosis. Immunotherapy 2010; 2: 159-169.

14. Rumbo M, Sierro F, Debard N, Kraehenbuhl J-P and Finke D. Lymphotoxin $\beta$ receptor signaling induces the chemokine CCL20 in intestinal epithelium. Gastroenterology 2004; 127: 213-223.

15. Hayat MA. Specific preparation methods. London: Academic press, 1986.

16. Carlson SA, Meyerholz DK, Stabel TJ and Jones BD. Secretion of a putative cytotoxin in multiple antibiotic resistant Salmonella enterica serotype Typhimurium phagetype DT104. Microb Pathog 2001; 31: 201-204. 
17. Smaldini P, Curciarello R, Candreva A, Rey MA, Fossati CA, Petruccelli $\mathrm{S}$, et al. In vivo evidence of cross-reactivity between cow's milk and soybean proteins in a mouse model of food allergy. Int Arch Allergy Immunol 2012; 158: 335-346.

18. Wentworth CC, Alam A, Jones RM, Nusrat A and Neish AS. Enteric commensal bacteria induce extracellular signal-regulated kinase pathway signaling via formyl peptide receptor-dependent redox modulation of dual specific phosphatase 3. J Biol Chem 2011; 286: 38448-38455.

19. Garton NJ and Sutcliffe IC. Identification of a lipoarabinomannan-like lipoglycan in the actinomycete Gordonia bronchialis. Arch Microbiol 2006; 184: 425-427.

20. Romier B, Van De Walle J, During A, Larondelle Y and Schneider Y-J. Modulation of signalling nuclear factor-kappaB activation pathway by polyphenols in human intestinal Caco-2 cells. Br J Nutr 2008; 100: 542-551.

21. Bandyopadhaya A, Sarkar M and Chaudhuri K. Transcriptional upregulation of inflammatory cytokines in human intestinal epithelial cells following Vibrio cholerae infection. FEBS $J$ 2007; 274: 4631-4642.

22. Ito T, Carson 4th WF, Cavassani KA, Connett JM and Kunkel SL. CCR6 as a mediator of immunity in the lung and gut. Exp Cell Res 2011; 317: 613-619.

23. Bandyopadhaya A and Chaudhuri K. Differential modulation of NF-kappaB-mediated pro-inflammatory response in human intestinal epithelial cells by cheY homologues of Vibrio cholerae. Innate Immun 2009; 15: 131-142.

24. Barnes PJ and Karin M. Nuclear factor-kappaB: a pivotal transcription factor in chronic inflammatory diseases. $N$ Engl $\mathrm{J} \mathrm{Med}$ 1997; 336: 1066-1071.

25. Iyer C, Kosters A, Sethi G, Kunnumakkara AB, Aggarwal BB and Versalovic J. Probiotic Lactobacillus reuteri promotes TNFinduced apoptosis in human myeloid leukemia-derived cells by modulation of NF-kappaB and MAPK signalling. Cell Microbiol 2008; 10: 1442-1452.

26. Chariot A. 20 years of NF-kappaB. Biochem Pharmacol 2006; 72 : 1051-1053.
27. Nandakumar NS, Pugazhendhi S, Madhu Mohan K, Jayakanthan K and Ramakrishna BS. Effect of Vibrio cholerae on chemokine gene expression in HT29 cells and its modulation by Lactobacillus GG. Scand J Immunol 2009; 69: 181-187.

28. Lodes MJ, Cong Y, Elson CO, Mohamath R, Landers CJ, Targan SR, et al. Bacterial flagellin is a dominant $\mathrm{Ag}$ in Crohn disease. J Clin Invest 2004; 113: 1296-1306.

29. Cremon C, Pallotti F, Bacchilega M, Stanghellini V, Corinaldesi $\mathrm{R}$ and Barbara G. Antiflagellin Abs suggest infective participation in irritable bowel syndrome pathogenesis. Exp Rev Gastroenterol Hepatol 2008; 2: 735-740.

30. Desreumaux P. [Digestive tract immunology and Crohn disease]. Arch Pédiatr 2004; 11: 539-541. ([in French].

31. Kaser A, Ludwiczek O, Holzmann S, Moschen AR, Weiss G, Enrich B, et al. Increased expression of CCL20 in human inflammatory bowel disease. J Clin Immunol 2004; 24: 74-85.

32. Docena G, Rovedatti L, Kruidenier L, Fanning A, Leakey NAB, Knowles $\mathrm{CH}$, et al. Down-regulation of p38 mitogenactivated protein kinase activation and proinflammatory cytokine production by mitogen-activated protein kinase inhibitors in inflammatory bowel disease. Clin Exp Immunol 2010; 162: 108-115.

33. Williamson E, Westrich GM and Viney JL. Modulating dendritic cells to optimize mucosal immunization protocols. J Immunol 1999; 163: 3668-3675.

34. Blázquez AB, Knight AK, Getachew H, Bromberg JS, Lira SA, Mayer L, et al. A functional role for CCR6 on proallergic $\mathrm{T}$ cells in the gastrointestinal tract. Gastroenterology 2010; 138 : 275-284.

35. Li XM, Serebrisky D, Lee SY, Huang CK, Bardina L, Schofield $\mathrm{BH}$, et al. A murine model of peanut anaphylaxis: T- and B-cell responses to a major peanut allergen mimic human responses. J Allergy Clin Immunol 2000; 106: 150-158.

36. Zuany-Amorim C, Sawicka E, Manlius C, Le Moine A, Brunet LR, Kemeny DM, et al. Suppression of airway eosinophilia by killed Mycobacterium vaccae-induced allergen-specific regulatory T-cells. Nat Med 2002; 8: 625-629. 